A N N A LES

UNIVERSITATIS MARIAE CURIE-SKŁODOWSKA

L U B L I N - P O L O N I A

VOL. LXVII, 1

SECTIO B

2012

Maria Curie-Skłodowska University in Lublin, Faculty of Earth Sciences and Spatial Management

Department of Cartography and Geomatics

\author{
KRZYSZTOF KAŁAMUCKI, ANNA KAMIŃSKA, DOROTA BUK
}

\title{
Spatial aspects of the research on tourist infrastructure with the use of the cartographic method on the basis of Roztoczański National Park
}

\author{
Przestrzenne aspekty badań infrastruktury turystycznej z zastosowaniem kartograficznej \\ metody badań na przykładzie Roztoczańskiego Parku Narodowego
}

\begin{abstract}
The aim of the research was to demonstrate changes in tourist trails and in the distribution of tourist infrastructure spots in the area of Roztoczański National Park in its vicinity. Another, equally important aim, was to check the usefulness of tourist infrastructure in both cartographic method of infrastructure research and in cartography of presentation methods.

The research covered the region of Roztoczański National Park. The following elements of tourist infrastructure were selected for the analysis: linear elements (walking trails, education paths) and spot elements (accommodation, eating places and the accompanied basis). In order to recreate the state of infrastructure during the last 50 years, it was necessary to analyse the following source material: tourist maps issued as independent publications, maps issued as supplements to tour guides and aerial photography. The information from text sources was used, e.g. from tourist guides, leaflets and monographs.

The temporal framework was defined as 50 years from the 1960's until 2009. This time range was divided into five 10-year periods. In order to present the state of tourist infrastructure, its spatial and qualitative changes, 6 maps were produces (maps of states and types of changes).

The conducted spatial analyses and the interpretations of maps of states and changes in tourist infrastructure allowed to capture both qualitative and quantitative changes. It was stated that the changes in the trails were not regular. There were parts of trails that did not change for 40 years. There were also some that were constructed during the last decade. Presently, the area is densely covered with tourist trails and education paths. The measurements of lengths of tourist trails and their parts with regard to land cover and category of roads allowed to determine the character of trails and the scope of changes.

The conducted analyses proved the usefulness of cartographic methods in researching tourist infrastructure in spatial and quantitative aspects.
\end{abstract}

Key words: tourist infrastructure, cartographic research method, spatial analyses, Roztoczański National Park 


\section{INTRODUCTION}

One of important components in the tourist space that is closely related to the size of tourist traffic is tourist infrastructure. Its relations to the tourist traffic are inseparable. It is tourist traffic that generates demand for tourist services and forces the development of tourist infrastructure. On the other hand, the infrastructure provides tourists with the reception area and tourist attractions as well as gives access to different types of tourist services.

Spatial distribution and changes in tourist infrastructure are closely related to the size and diversity of tourist traffic. When the number of tourists rises, the infrastructure does the same; when it falls, the infrastructure is in a serious crisis. Thus, there is a strong positive correlation between these phenomena. Researching tourist infrastructure changes in time and space, one can directly conclude about the changes in size and the intensity of tourist traffic in the area.

Tourist infrastructure is the object of research of geography, including cartography. Geographers' and cartographers' interest in tourist infrastructure results from its spatial character. Out of 14 research directions and concepts described by Kurka and Mika (2007) there are 7 which are related to space. They are: the concept of tourist space, theory of periphery, the concept of territorial recreation spaces and model of evolution cycle in tourist area, among others. Tourist space is understood as part of geographical space (physical-geographic, social, cultural and economic) in which all tourist phenomena take place (Warszyńska, Jackowski 1979).

Cartography as scientific and practical discipline is concerned with the description of spatial phenomena and processes. The number of research concerning spatial analyses in tourism has risen recently. Cartographic research methods are more and more frequently used in tourist research not only by geographers, but also by many experts from other fields. They often use maps to present the results of their research. Therefore, there is a need to incorporate cartography into the stream of tourist research.

The aim of the research was to demonstrate changes in tourist trails and in the distribution of tourist infrastructure spots in the area of Roztoczański National Park and in its vicinity. Another, equally important aim, was to check the usefulness of tourist infrastructure in both cartographic method of infrastructure research and in cartography of presentation methods.

\section{THE RANGE OF RESEARCH}

The research covered selected elements of tourist infrastructure such as linear elements: walking trails, education paths and spot elements: accommodation, eating places, and the accompanied basis. 
Tourist trails are the fragments of roads, paths, skiing routes, lowland and mountain, water flows and water bodies, which are systematically frequented by tourists due to their tourist values, i.e. they are the routes of walks and tourist excursions. The Central Statistical Office defines tourist trails in the following way: they are routes (primarily for pedestrians) marked in the terrain due to its landscape values (with consideration to tourist safety and environment protection and marking them with conventional marks that help find the right way - advisory or obligatory (Turystyka w $2007 \mathrm{r}$., 2008). Tourist trails must have distinctive marks, so that they do not cause any doubts. They should also have a clear method of marking. They should also mark the most attractive and comfortable route to the destination point. At the same time, they must provide safety in different weather conditions.

In order to help tourist contact the nature in Roztocze, numerous walking and water trails have been outlined and marked. This primarily concerns the most interesting places in the area of Roztoczański National Park. The first marked tourist trails were outlind in the area as late as in the 1960's. It was Polish Tourist and Sightseeing Society (Polskie Towarzystwo Turystyczno-Krajoznawcze) that had a large influence on the development of tourist trails in Roztocze.

Apart from walking trails, in the area there are also education paths and cycle routes. Education paths are an example of linear element of tourist infrastructure. Their length is much shorter than walking trails and reaches at most a few kilometres. The aim of outlining education paths was to know the elements of the nature and places related to important historic events, commemorating people who were important for the region. That is why the names of the trails are so important. They can be education paths, didactic and ecological, historic and many more. In the area of the Park, there are 9 education paths.

The accommodation facilities are among basic elements of tourist infrastructure. The main function of accommodation base is to provide tourists with accommodation, guarantee safety and hygiene. Accommodation ranges depending on the facilities. According to the data by the Central Statistical Office, tourist facilities are defined as "the objects that offer accommodation in rooms or other halls, however, the number of beds must be higher than the defined minimum that results from the needs of an individual family. All the beds in the location must be managed by single management team, even if the place is not focused on profit generation" (Turystyka w 2007 r., 2008).

The Central Statistical Office has as many as 19 types of group accommodation. There are: hotels, motels, boarding houses, travel lodges, hostels, youth hostels, holiday houses, resort hotels, training centres, creativity houses, tourist houses, camping, campsites, weekend houses, spas and other tourist buildings. Individual night accommodation includes guest rooms and agrotourism houses.

The bill on tourist services defines only 8 types of hotel facilities: hotels, 
motels, boarding houses, camping, and travel lodges, youth hostels, hostels and camps (The bill on tourist services). The division of the accommodation services does not meet author's requirements, therefore, the present article uses the division offered by CSO (Central Statistical Office).

After the analysis of source materials concerning the object of the research the following facilities were selected: hotel, boarding house, youth hostel, resort hotel, a camp, agrotourism lodgings, and a guest house.

Apart from accommodation facilities, the eating place base was analysed. It is an important element of tourist infrastructure. Due to the types of services they render, the institutions can be divided into three types:

- eating places in hotels, related to serving tourists;

- other eating places located in the places frequented by tourists, such as historic city centres, major tourist attractions, train stations, i.e. the placed that are focused on serving travellers;

- other places that serve local people, rarely tourists.

The elements of the eating places that were analysed were the following: restaurants, bars, coffee shops, patisseries, beer pubs and canteens. The facilities that function with accommodation facilities were not chosen for the analysis, as they are accompanying services for those who use accommodations services. In the 1960's - 1980's there were specific eating places - taverns. They were eating places with waiter services organised in rural areas. Grocery shops are also counted in this category. These facilities were not analysed as they are common places. If at the beginning of the research period shops were characteristic of larger towns and were usually described in tourist guides from that time, they have been common in most villages nowadays. More importantly, marking all these places might be difficult from cartographic point of view.

The functioning of communication, accommodation and eating facilities constitute a basic tourist base, which is indispensible to perform most forms of tourism. In order to meet all users' expectations, the facilities must be equipped with appliances that supplement the basis offer. These are services and institutions of different character: services, entertainment, culture, sports which generate additional tourist values or facilitate the use of basic values (Gaworecki, 2003).

For the purposes of the present research, the following accompanying facilities were selected for the analysis: bathing beaches, ski resorts, water sports rental and sports rental. These are the facilities that make a tourist attraction themselves or even a tourist destination on its own.

The research was conducted in the region of Roztoczański National Park. The selected area is the place where the influence of the park is most noticeable. It is part of central Roztocze, a square area whose borders are marked by city borders of Szczebrzeszyn in the north, Józefów in the south, and Krasnobród in the east. 
Spatial aspects of the research on tourist infrastructure with the use of the cartographic... 249

\section{METHODOLOGY OF REASECH}

One of the basic methodological assumptions in the research was the broadest possible use of old and contemporary maps and other cartographic sources. These sources included: tourist maps, issued as independent publications, maps issued as supplements to tour guides and aerial photography. After initial analysis, it turned out that the maps from the first group, issued in the previous century, were prepared with a small scale (most often 1:125 000). They are over-generalised and outdated in many places. Their credibility is doubtful, therefore, they cannot be the only source. The maps issued as supplements to tourist guides appeared more credible, however, their small scale prevented their full use. It was decided to use archive aerial photos. They were helpful with reconstructing tourist trails and with locating tourist facilities.

Due to low credibility of the old tourist maps the information from text sources was used, e.g. tourist guides, leaflets and monographs. They included detailed information concerning the outline and marking of tourist trails in different periods, as well as information about accommodation, eating facilities and other attractions that were presented in the maps.. The complete selection of the materials (cartographic and textual) is presented in Table 1. The sources are presented in thematic an chronological order.

On the basis of information obtained from the textual and cartographic source material (Tab. 1) the temporal framework was defined in which the changes in tourist infrastructure took place in the area of Roztoczański National Park and in its vicinity. The temporal framework was defined as 50 years from the 1960's until 2009. This time range was divided into 10-year periods, in order to present the conditions in each decade (the 60's, 70's, 80's, 90's) and the present day. Such division was also determined by the establishment of Roztoczański National Park in 1974 and increasing its area in 1979, 1990 and 1995. The time ranges were chosen in such a way as to enable the presentation of the conditions and infrastructure changes before the establishment of the Park.

The choice of research method is a significant problem in methodology of the research. The research on infrastructure change can be done with a number of methods, including qualitative and quantitative methods. Due to the fact that tourist infrastructure is dispersed in space, cartographic methods seem to be the best to do such experiments. Cartography as science and practical discipline not only deals with making maps but also develops specific research methods which are called cartographic research method.

Map as a communication tool used to convey the information, apart from its basic property to reflect the features of object arrangement, is also used to evaluate the phenomena and the object. Therefore, the basic criterion of cartographic classification of the presentation methods should be the differentiation of qualitative and quantitative characteristics (Ratajski, 1989). 
Table 1. Source materials used in division into periods

\begin{tabular}{|c|c|c|c|c|}
\hline Year & Tour guides & Maps & Aerial photos & Periods \\
\hline 1955 & $\begin{array}{l}\text { M. Bonkowicz, } \\
\text { Roztocze Lubelskie }\end{array}$ & & & \multirow{4}{*}{ 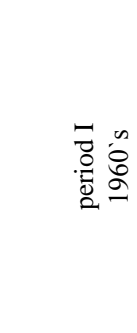 } \\
\hline 1961 & & $\begin{array}{l}\text { Tourist map of Central Roztocze } \\
1: 125000\end{array}$ & & \\
\hline 1964 & & & $\begin{array}{l}\text { Aerial photos } \\
1: 16000\end{array}$ & \\
\hline 1968 & & $\begin{array}{l}\text { Tourist map of Central Roztocze } \\
1: 125000\end{array}$ & & \\
\hline 1971 & K. Izdebski et al., Roztocze & & & \multirow{4}{*}{ تُ } \\
\hline 1974 & $\begin{array}{c}\text { J. Buraczyński, } \\
\text { Roztocze Tomaszowskie }\end{array}$ & & & \\
\hline 1977 & W. Wójcikowski et al., Roztocze & & & \\
\hline 1978 & & $\begin{array}{c}\text { Tourist map of Central Roztocze } \\
1: 125000\end{array}$ & $\begin{array}{l}\text { Aerial photos } \\
1: 33000\end{array}$ & \\
\hline 1984 & $\begin{array}{c}\text { G. Rąkowski, } \\
\text { Przez trzy puszcze }\end{array}$ & $\begin{array}{c}\text { Tourist map of Central Roztocze } \\
1: 125000\end{array}$ & $\begin{array}{l}\text { Aerial photos } \\
1: 25000\end{array}$ & \multirow{2}{*}{ 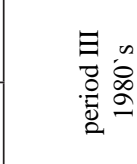 } \\
\hline 1984 & $\begin{array}{c}\text { S. Stolarczyk, } \\
\text { Roztocze Środkowe }\end{array}$ & & & \\
\hline 1994 & $\begin{array}{c}\text { T. Wilgat (ed.), } \\
\text { Roztoczański Park Narodowy }\end{array}$ & $\begin{array}{c}\text { Tourist map of Central Roztocze } \\
\text { 1: } 100000\end{array}$ & & \multirow{3}{*}{ 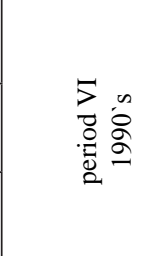 } \\
\hline 1997 & $\begin{array}{c}\text { A. Pawłowski, Roztocze } \\
\text { Polskie... }\end{array}$ & & & \\
\hline 1998 & E. Słoniewski, Roztocze & & $\begin{array}{l}\text { Aerial photos } \\
1: 26000\end{array}$ & \\
\hline 2000 & & $\begin{array}{c}\text { Tourist-natural map of Roztoczań- } \\
\text { ski National Park } \\
1: 50000\end{array}$ & & \multirow{5}{*}{ 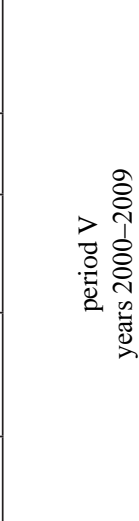 } \\
\hline 2003 & $\begin{array}{c}\text { A. Pawłowski, } \\
\text { Roztocze Środkowe }\end{array}$ & & $\begin{array}{l}\text { Aerial photos } \\
1: 13000\end{array}$ & \\
\hline 2005 & & $\begin{array}{c}\text { Tourist-natural map of Roztocze } \\
\text { National Park } \\
\text { 1: } 50000\end{array}$ & & \\
\hline 2006 & $\begin{array}{l}\text { T. Grabowski (ed.), Roztoczań- } \\
\text { ski Park Narodowy, Poludniowa } \\
\text { oś przyrodniczo-edukacyjna }\end{array}$ & $\begin{array}{l}\text { Tourist map of Central Roztocze } \\
1: 50000\end{array}$ & & \\
\hline 2007 & $\begin{array}{c}\text { T. Grabowski (ed.), Informator: } \\
\text { Edukacja i turystyka }\end{array}$ & & & \\
\hline
\end{tabular}

Source: Author`s study 
In the work, both cartographic research methods and cartographic presentation methods were used.

The first step was to catalogue the state of tourist infrastructure in 5 periods. Then a spatial database of tourist infrastructure in each period was created. It covered all of the previous elements. The distribution of the items and the outline of linear elements of tourist infrastructure in each of the researched periods was presented on 5 maps of the state. The arrangement of the maps one after another allowed to observe the changes and their dynamics. They show a significant rise of spot items in tourist infrastructure in Zwierzyniec itself and its vicinity. The observations prove the increase in the number of tourist trails and changes in their layout.

However, comparing 5 maps is difficult and problematic. This method does not guarantee capturing all the differences. With regard to the above, other maps were drafted. They present most important changes in selected elements of tourist infrastructure.

For this reason, a multiphase map of linear elements change was drafted (Fig. 1) as well as the map of the types of these changes. In the first map there are linear markers of changeable width and different colours. The "oldest" trails (from the 1960's) were marked with the widest line, while the newest (from the first years of the $21^{\text {st }}$ cent.) are the thinnest. In this way many phases of changes in the research were presented. The cartographic method of data presentation shows the most important changes in tourist trail layout in an unambiguous and clear way.

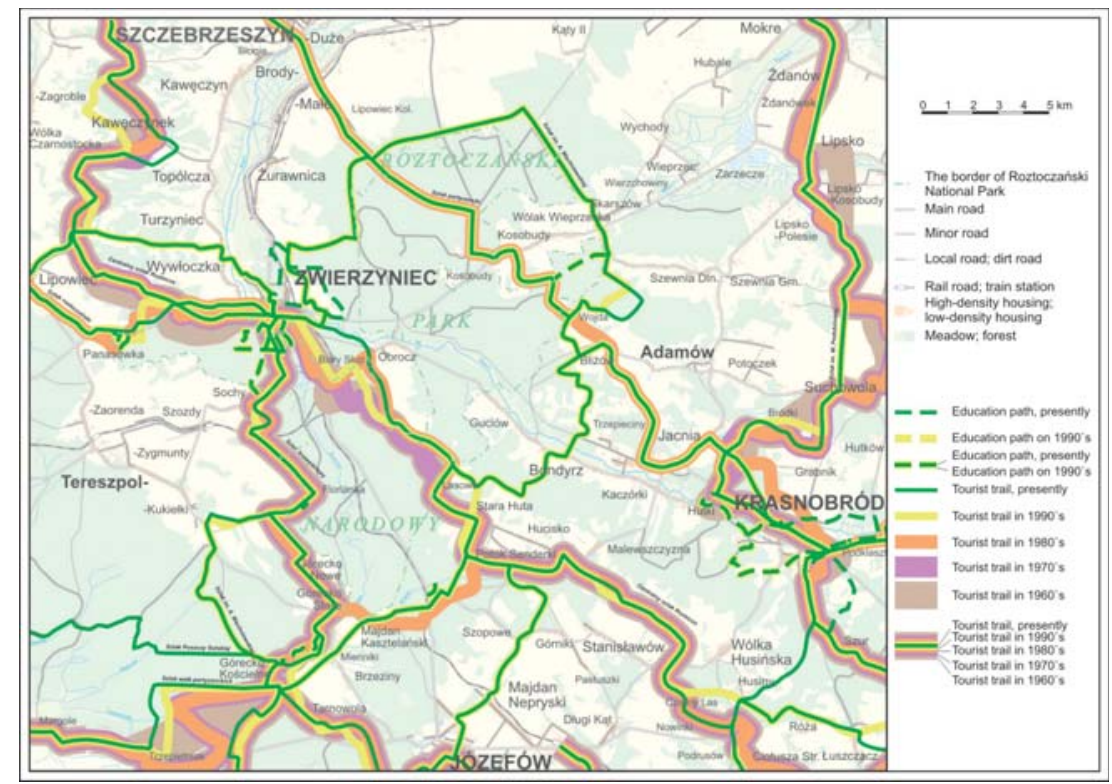

Fig. 1. The routes of education paths and tourist trails in the vicinity of Roztoczański National Park in several periods 
It was stated that the changes in trail routes were irregular. There were trails that had not changed their route for 40 years. There were also the trails that were marked during the last decade.

Very complex image of multiphase map made authors simplify the presentation and show the results in a form of map of the change type (Fig. 2). After detailed analysis 6 types of changes were selected:

- Type I - the presence of tourist trails during the first two periods (1960's and 1970's);

- Type II - the presence of tourist trails during the first three periods (1960's, 1970's and 1980's);

- Type III - the presence of tourist trails during all five periods;

- Type IV - the presence of tourist trails during the three last periods (1980's and 1990's and 2000-2009);

- Type V - the presence of tourist trails during the last two periods (1990's and 2000-2009);

- Type VI - the presence of tourist trails during the last season (2000-2009) (Fig. 2).

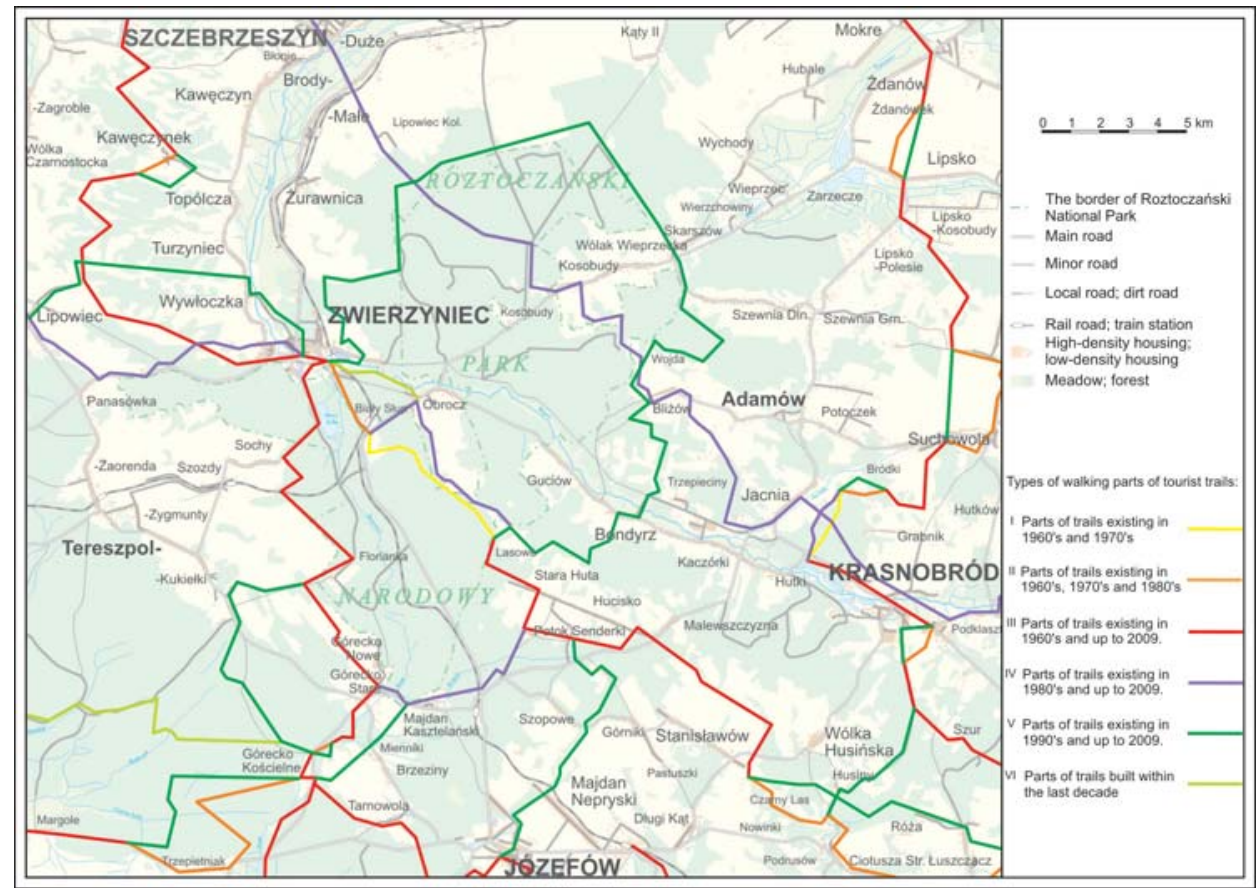

Fig. 2. The types of changes in walking tourist trails in the vicinity of Roztoczański National Park in several periods 
In order to present the spot elements of tourist infrastructure a map of changes was also done. However, due to a small scale of the map, it was impossible to present the changes in Zwierzyniec. Therefore, Zwierzyniec was presented on a separate map in a larger scale (Fig. 3).

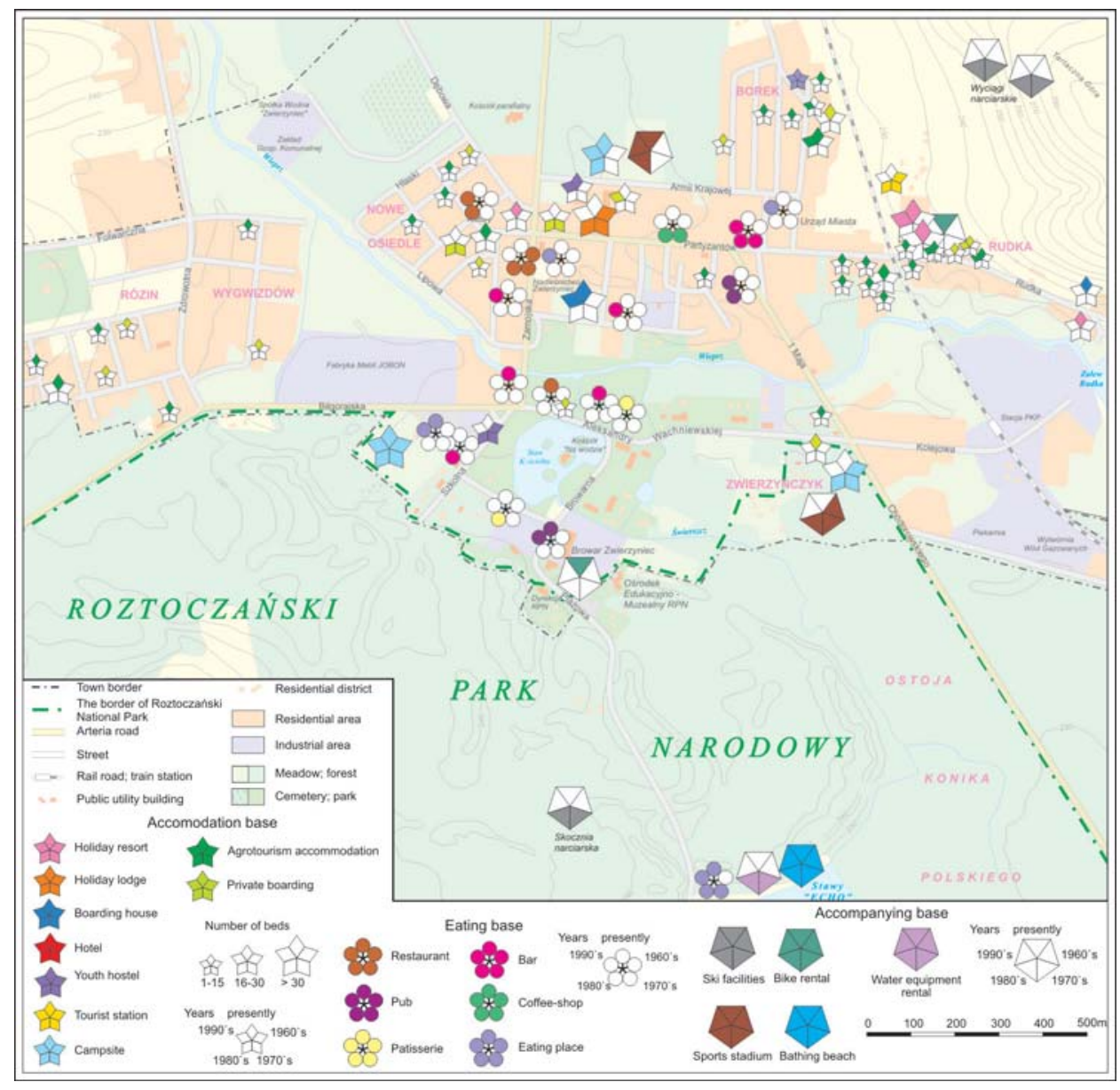

Fig. 3. The changes in spot tourist infrastructure in Zwierzyniec

The aim of creating these maps was to show the accommodation, eating and additional services in one map. In order to present the dynamics of spot phenomena, the method of localised polar graphs was used (Saliszczew, 1998; Ratajski, 1989).

In order to present three types of tourist infrastructure, three forms of graphs were selected. All of them were constructed in a similar manner. Each of them consisted of 5 elements, which made a complete figure (a star, a pentagon, a flower 
with five "petals") (Fig. 3). Each element symbolised one period, which changed clockwise.

Such a graph was placed in a spot where a given object of tourist infrastructure was located, regardless of the decade. The presence of the object in a particular period is marked with appropriate part of the graph being coloured. All the signatures: stars, "flowers" and pentagons, have different colours. Different colours are also attributed to different object, e.g. hotels, coffee-shops or a ski-lift (Fig. 3).

\section{THE ANALYSIS OF SPATIAL CHANGES OF TOURIST INFRASTRUCTURE}

The analysis of spatial changes of tourist infrastructure was carried out on the basis of the prepared maps and cartometric analyses with the use of ArcGIS programme. One can see in Figures 1 and 2 that the route of tourist trails underwent constant, yet irregular changes. Some of them were liquidated, others are kept in the same places for years. The measurements of the trail length show that the increase in the total length was evident and had the largest values in the 1990's (Tab. 2). There are also cases of changes in certain parts of trails. Such a situation happened in the 1970's when Roztoczański National Park was established and the changes concerned the area of the Park and its vicinity (Fig. 2, type of changes I and II). The facts that almost one third of trails have never been changed and another third of the trails have existed since the 1990's prove the stability of tourist trail system in the area. Presently, the area is covered with a dense network of tourist trails that run through the most attractive areas and concentrate in the largest tourist centres, e.g. Zwierzyniec and Krasnobród.

Initially, there were three marked tourist trails marked as The Central Trail (bule), the Edge Trail (red) and the Bicycle Route (green). In the 1970's the Trail of Great Partisans' Fights Trail was outlined. In the next decade another trails were created: the Roztoczański Trail, Ziemia Józefowska Trail, Partisans' Trail and the Linking Trail that links Krasnobród with Górecko Stare. In the 1990's the renovation of trail marks was carried out. In total, there was one marked tourist trail in the 1990's. Presently, there are 12 marked tourist trails with a total length of $269 \mathrm{~km}$ (Tab. 2).

In order to fulfil the educational functions of the Park, 9 education paths were outlined. Their aim was to funnel the tourists to attractive sites and leave the most precious parts of the nature in the park untouched by tourists. The creation of education paths in the park was to be a form of compensation for moving parts of some trails outside the park. Some education paths were also created outside the park. Recently new paths were marked: a walking path from Krasnobród to Szur, nature-history education path around Krasnobród, a path to Kamienna Góra in Zwierzyniec, a path to Tartaczna Góra in Zwierzyniec, Senderki - Kistków - Stara 
Spatial aspects of the research on tourist infrastructure with the use of the cartographic... 255

Huta trail and a path Szczebrzeszyn - Kawęczynek. Most education trails were built or renovated around Zwierzyniec and Krasnobród.

Table 2. List of tourist trails researched in the vicinity of Roztoczański National Park in several periods

\begin{tabular}{|c|c|c|c|c|c|}
\hline Years & 1960's & 1970's & 1980's & 1990's & 2000-2009 \\
\hline \multirow{12}{*}{ 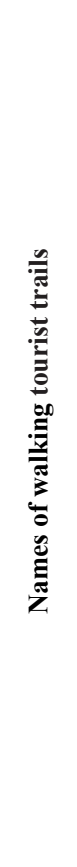 } & Centralny & Centralny & Centralny & Centralny & Centralny \\
\hline & Krawędziowy & Krawędziowy & Krawędziowy & Krawędziowy & Krawędziowy \\
\hline & Rezerwatów & Rezerwatów & Rezerwatów & $\begin{array}{c}\text { im. W. } \\
\text { Podobińskiej }\end{array}$ & $\begin{array}{c}\text { im. W. } \\
\text { Podobińskiej }\end{array}$ \\
\hline & $\begin{array}{c}\text { Walk } \\
\text { partyzanckich }\end{array}$ & $\begin{array}{c}\text { Walk } \\
\text { partyzanckich }\end{array}$ & $\begin{array}{c}\text { Walk } \\
\text { partyzanckich }\end{array}$ & $\begin{array}{c}\text { Walk } \\
\text { partyzanckich }\end{array}$ & $\begin{array}{c}\text { Walk } \\
\text { partyzanckich }\end{array}$ \\
\hline & & $\begin{array}{c}\text { Ziemi } \\
\text { Józefowskiej }\end{array}$ & $\begin{array}{c}\text { Ziemi } \\
\text { Józefowskiej }\end{array}$ & $\begin{array}{c}\text { Ziemi } \\
\text { Józefowskiej }\end{array}$ & $\begin{array}{c}\text { Ziemi } \\
\text { Józefowskiej }\end{array}$ \\
\hline & & & Partyzancki & Partyzancki & Partyzancki \\
\hline & & & Roztoczański & Roztoczański & Roztoczański \\
\hline & & & Łącznikowy & $\begin{array}{c}\text { im. A. } \\
\text { Wachniewskiej }\end{array}$ & $\begin{array}{c}\text { im. A. } \\
\text { Wachniewskiej }\end{array}$ \\
\hline & & & & Łącznikowy I & Łącznikowy I \\
\hline & & & & Łącznikowy II & Łącznikowy II \\
\hline & & & & Łącznikowy III & Łącznikowy III \\
\hline & & & & & Puszczy Solskiej \\
\hline 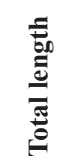 & $134 \mathrm{~km}$ & $136 \mathrm{~km}$ & $185 \mathrm{~km}$ & $252 \mathrm{~km}$ & $269 \mathrm{~km}$ \\
\hline
\end{tabular}

Source: Author's study

Apart from changes in linear tourist infrastructure, a dynamic development of spot elements was noted in the area. These objects were concentrated around main tourist centres in the area, namely Zwierzyniec in the north-western part (Fig. 3), Krasnobród in the eastern part, and Józefów in the southern part of the examined area.

Initially, in the 1960's, youth hostels in Józefów, Krasnobród, Zwierzyniec and Szczebrzeszyn were available for tourists. Later on, tourist stations in Górecko Kościelne, Józefów, Zwierzyniec, a hotel in Szczebrzeszyn and a campsite near the 
sports stadium: "Sokół" in Zwierzyniec were opened (Izdebski et al, 1971). The main eating places were represented by taverns in Adamów, Józefów, Kransobród, Szczebrzeszyn, and Zwierzyniec. From the 1960's on, the use of present Park for group outings was more and more intensive. In the following years a tourist lodge in Zwierzyniec, campsites in Józefów, Krasnobród and Obrocza were made available for tourists. There were also private guest houses in Józefów, Krasnobród and Zwierzyniec available for tourists. All in all, in the 1970's there were around 700 beds available in Roztoczański National Park and in its vicinity (Kroniki RNP...). Eating facilities also developed. "Roztocze" restaurant was opened in Zwierzyniec; bar and cafeteria, and "Turystyczna" restaurant in Krasnobród; restaurant, bar and canteen in Józefów, and two restaurants in Szczebrzeszyn were established (Wójcikowski, Paczyński 1977). Other tourists attractions were also made available including bathing beach, tourist equipment rental and sports pitch in Krasnobród, sports stadium in Zwierzyniec, "Echo" bathing beach and tourist equipment rental (Fig. 3).

After the establishment of Roztoczański National Park, all efforts were placed to move tourist infrastructure outside the Park, and even outside its protected areas. These activities intensified in 1979, when the area of the Park was extended by another 2,000 hectares. The park had numerous objects and tourist facilities related to sports and leisure. Park administration liquidated the infrastructure that was intended for mass tourism, including campsite in the forest near Zwierzyniec, bungalows near "Echo" ponds, in the Wieprz valley near Obrocza, sports stadium, forest ski jump, water equipment rental at "Echo" ponds, services at "Echo" ponds, etc. At that time, the Park not only removed chaotic and poorly organised tourist infrastructure, but also applied for moving the locations of mass tourism and sports events (sleigh ride, ski runs) outside the park (Grabowski et al. 2004).

In the 1980's artificial lakes in Krasnobród and Józefów were given for tourism purposes. Also ski lifts were organised for tourists: two in Zwierzyniec on Góra Tartaczna, two in Szczebrzeszyn, and two in Krasnobród - one on Góra Chełmowa and Babka mountain (Stolarczyk 1984).

The 1990's brought further development of tourist infrastructure that is the object of the analysis. Due to the possibility to conduct entrepreneur activities by natural persons, new offers of accommodation, such as guest houses and accommodation in private homes, appeared in the market. The facilities were available mainly in the direct vicinity of the Park, especially in Zwierzyniec but also in Sochy and other villages on the route between Zwierzyniec and Krasnobród: Obrocz, Guciów, Bondyrz, Hutki. New tourist facilities developed also in Krasnobród and Józefów.

The continuation of trends that started in the 1990's can be seen presently. Accommodation facilities, especially agrotourism accommodation, private boarding houses and eating places are still developing. 


\section{THE DERIVATIVE ANALYSIS OF TOURIST INFRASTRUCTURE}

The creation of spatial database of tourism infrastructure in the research can do numerous spatial and geostatic analyses. One of the aims of the research was to calculate and present the density of tourist trails in a form of a map (Fig. 4). It shows that small differences in trail density and its highest value were noted in the region of Zwierzyniec, Adamów, Górecko Kościelne and Krasnobród (ca. 3 km/km²).

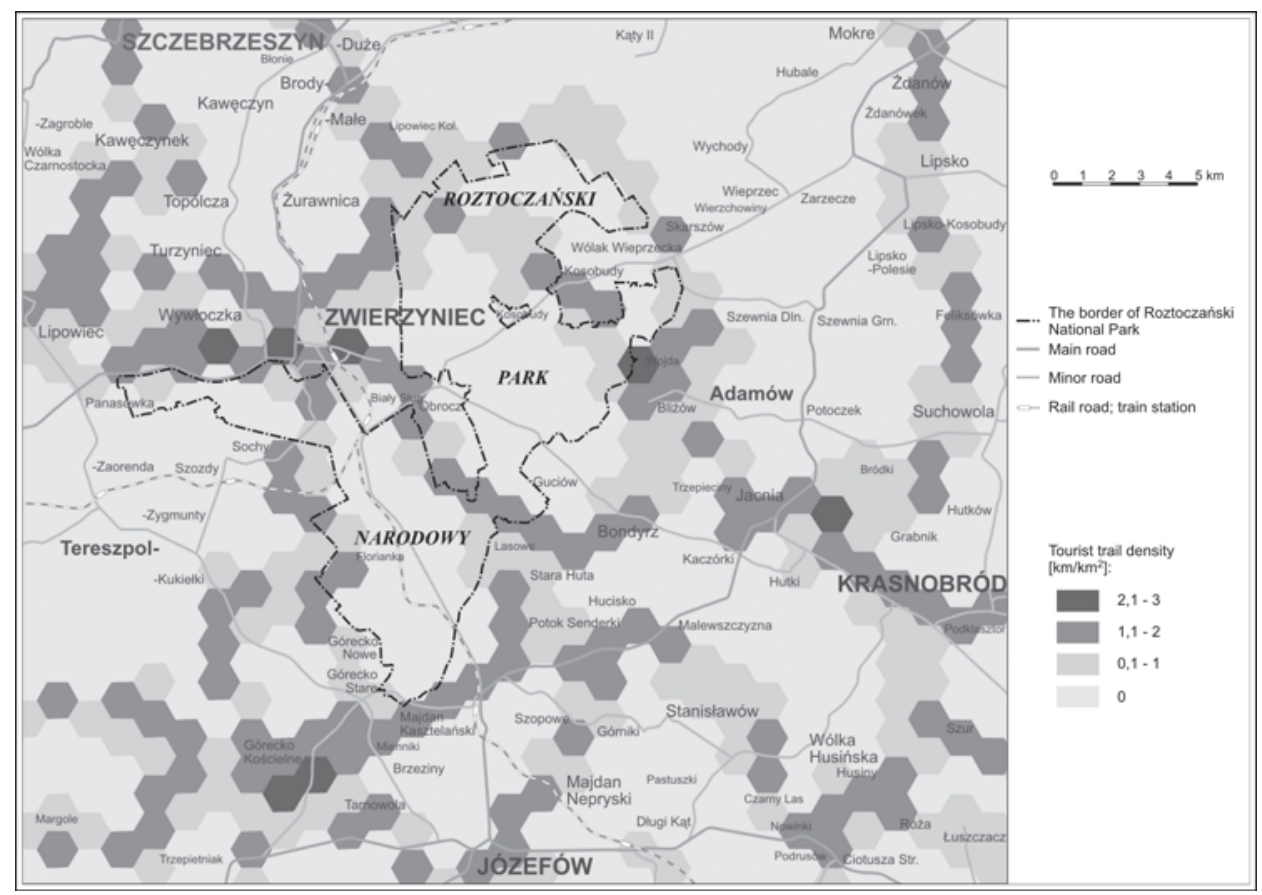

Fig. 4. The density of tourist trails in the vicinity of Roztoczański National Park

An attempt to compare the spot arrangement of tourist infrastructure along tourist trails and roads within $1 \mathrm{~km}$ from roads and trails was made (Fig. 5). It was noticed that there was no correlation between these elements. The location of spots is related to the existing settlement network rather than to the trail network. The highest density of tourist infrastructure is noted in Zwierzyniec and Szczebrzeszyn (the number ranges from 7 to 12) and in major villages, where their number does not exceed 6 spots per $1 \mathrm{~km}^{2}$. 


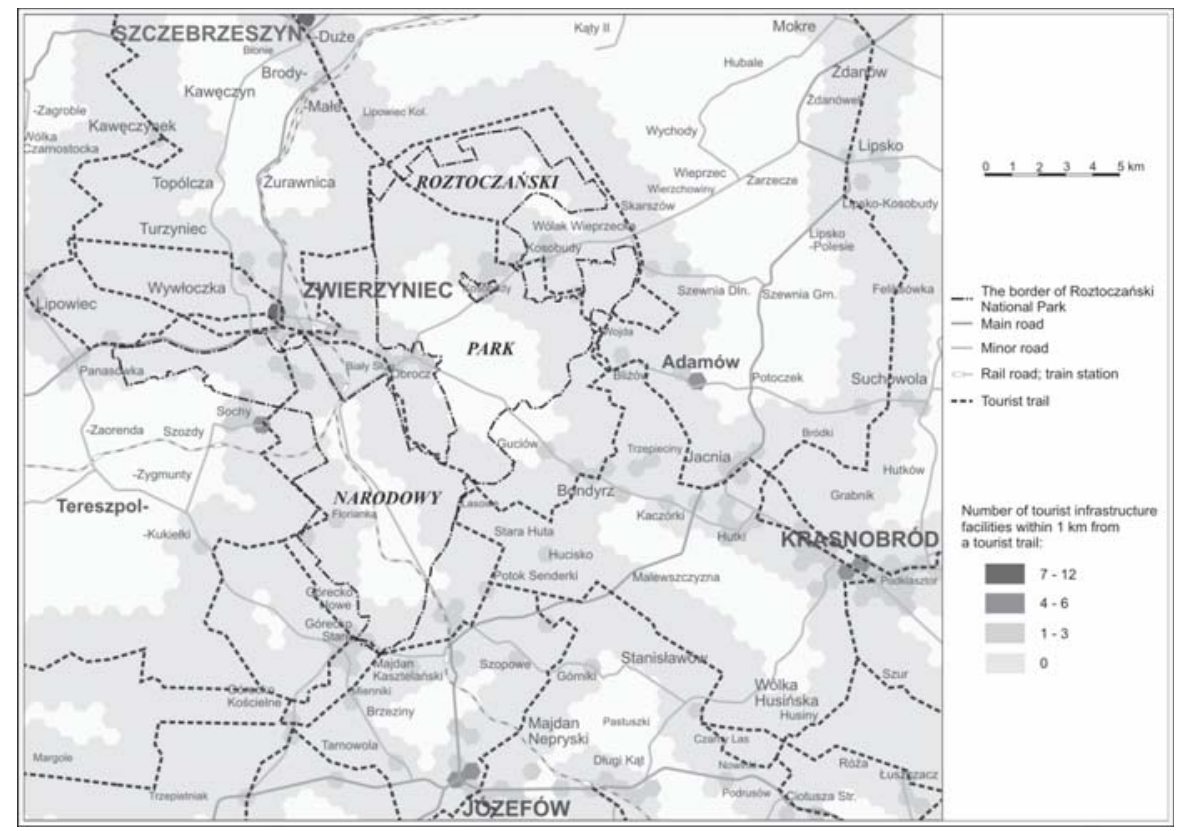

Fig. 5. The distribution of spot elements in tourist infrastructure with regard to the tourist trails in the vicinity of Roztoczański National Park

Interesting conclusions can be drawn from the analysis of the terrain on which the trail runs. Five types of land covers were numbered: fields, meadows, forest edge, forests and built-up areas. The length of all the trails that run through these lands was calculated. The results are presented in Table 3. It turns out that in all the periods more that $50 \%$ of the trails run through forests or their vicinity. In the 1990's and in the first years of the 2000's the length of trails running through fields decreased, while the length of trails running in built-up areas increased its share (Tab. 3).

Table 3. The length of tourist trails acc. to the type of land cover

\begin{tabular}{|l|r|r|r|r|r|r|r|r|r|r|}
\hline \multirow{2}{*}{$\begin{array}{l}\text { Types of land } \\
\text { cover }\end{array}$} & \multicolumn{2}{|c|}{1960 's } & \multicolumn{2}{|c|}{ 1970's } & \multicolumn{2}{|c|}{ 1980's } & \multicolumn{2}{|c|}{ 1990's } & \multicolumn{2}{|c|}{ 2009 } \\
\cline { 2 - 11 } & {$[\mathbf{k m}]$} & {$[\%]$} & {$[\mathbf{k m}]$} & {$[\%]$} & {$[\mathbf{k m}]$} & {$[\%]$} & {$[\mathbf{k m}]$} & {$[\%]$} & {$[\mathbf{k m}]$} & [\%] \\
\hline Fields & 43 & 32,1 & 46 & 33,9 & 56 & 30,3 & 62 & 24,6 & 62 & 23,0 \\
\hline Forest edge & 15 & 11,2 & 15 & 11,0 & 28 & 15,1 & 41 & 16,3 & 43 & 16,0 \\
\hline Forests & 57 & 42,5 & 57 & 41,9 & 74 & 40,0 & 108 & 42,8 & 117 & 43,5 \\
\hline Meadows & 2 & 1,5 & 3 & 2,2 & 6 & 3,2 & 5 & 2,0 & 5 & 1,9 \\
\hline Built-up areas & 17 & 12,7 & 15 & 11,0 & 21 & 11,4 & 36 & 14,3 & 42 & 15,6 \\
\hline Total length & 134 & 100 & 136 & 100 & 185 & 100 & 252 & 100 & 269 & 100 \\
\hline
\end{tabular}

Source: Author's study 
The types of roads along which tourist trails run are presented in Table 4. It shows that most trails run along dirt roads (over $60 \%$ of the total length). It should be mentioned that the share of roads that run along the main roads decreased (see Tab. 1).

Tab. 4. The length of tourist trails acc. to the type of roads

\begin{tabular}{|c|c|c|c|c|c|c|c|c|c|c|}
\hline \multirow{2}{*}{ Types of roads } & \multicolumn{2}{|c|}{ 1960's } & \multicolumn{2}{|c|}{ 1970's } & \multicolumn{2}{|c|}{ 1980's } & \multicolumn{2}{|c|}{ 1990's } & \multicolumn{2}{|c|}{2009} \\
\hline & {$[\mathrm{km}]$} & {$[\%]$} & {$[\mathrm{km}]$} & {$[\%]$} & {$[\mathrm{km}]$} & {$[\%]$} & {$[\mathrm{km}]$} & {$[\%]$} & {$[\mathrm{km}]$} & {$[\%]$} \\
\hline Main road & 9 & 6,7 & 7 & 5,1 & 12 & 6,6 & 9 & 3,6 & 9 & 3,3 \\
\hline Minor road & 20 & 14,9 & 17 & 12,5 & 33 & 17,6 & 36 & 14,3 & 40 & 14,9 \\
\hline Paved road & 5 & 3,8 & 7 & 5,1 & 9 & 5,1 & 14 & 5,5 & 18 & 6,7 \\
\hline Dirt road & 83 & 61,9 & 86 & 63,3 & 102 & 55,1 & 156 & 61,9 & 172 & 63,9 \\
\hline Path & 7 & 12,7 & 19 & 14,0 & 29 & 15,6 & 37 & 14,7 & 30 & 11,2 \\
\hline Total length & 134 & 100 & 136 & 100 & 185 & 100 & 252 & 100 & 269 & 100 \\
\hline
\end{tabular}

Source: Author's study

The analysis of tourist trails in terms of ground gradients was conducted. Around $30 \mathrm{~km}$ of trails run along the steepest slopes (over 10\%), which makes $11.9 \%$ of all the trails.

\section{CONCLUSIONS}

The research showed significant qualitative and quantitative changes in the tourist infrastructure in Roztoczański National Park and in its direct vicinity. The marked tourist trails in the area were established in the 1960's. The analyses and maps produced as well as the textual material that was analysed during the research show that the number of tourist trails in and near the Park has been growing since the 1990's. Significant growth of spot elements, such as accommodation and eating facilities, has also been noticed. The development of these elements of tourist infrastructure is primarily noticed in the vicinity of the park, in such towns as Zwierzyniec, which serves as a "gate" to the park. Therefore, the indirect influence of the Park on the development of accommodation and eating facilities can be observed. The research showed that over $50 \%$ of the trails run through forests or their vicinity and about $1 / 3$ of their length remained unchanged, which proves the stability of all the elements of the infrastructure. The conducted analyses proved the usefulness of cartographic methods in researching tourist infrastructure in spatial and quantitative aspects. The results may be used to plan tourist infrastructure, evaluate and revive tourist trails in the future. 


\section{Books}

\section{REFERENCES}

Bonkowicz M., 1955: Roztocze Lubelskie. Warszawa, 132.

Buraczyński J., 1974: Roztocze Tomaszowskie. Informator, Lublin, 31.

Gaworecki W. W., 2003: Turystyka, Polskie Wydawnictwo Ekonomiczne, Warszawa, 437.

Grabowski T., Kotuła Z., Kałamucki K., 2004: Obszary chronione stymulatorem rozwoju turystyki na przykładzie Roztoczańskiego Parku Narodowego, [in:] Z. Michalczyk (ed.), Badania geograficzne w poznawaniu środowiska. Wydawnictwo UMCS, Lublin, 826.

Grabowski T. (ed.), 2006: Roztoczański Park Narodowy. Poludniowa oś przyrodniczo-edukacyjna Zwierzyniec - Florianka - Górecko Kościelne, Roztoczański Park Narodowy, Zwierzyniec, 128.

Grabowski T. (ed.), 2007: Informator: Edukacja i turystyka w Roztoczańskim Parku Narodowym, RPN, Kartpol, Zwierzyniec, 52.

Izdebski K., Grądziel T., 1971: Roztocze, Wiedza Powszechna, Warszawa, 190.

Kroniki RPN 1974-2000, Zwierzyniec.

Kurek W., Mika M., 2007: Turystyka jako przedmiot badań naukowych, [in:] W. Kurek (ed.), Turystyka. Wydawnictwo Naukowe PWN, Warszawa, 540.

Pawłowski A., 1997: Roztocze Polskie, Puszcza Solska i Lasy Janowskie, S. Kryński, Warszawa, 304.

Pawłowski A., 2003: Roztocze Środkowe, Wydawnictwo Naukowe, Turystyczne i Edukacyjne, Mielec, 304.

Ratajski L., 1989: Metodyka kartografii społeczno-gospodarczej, PPWK, Warszawa, 337.

Rąkowski G., 1984: Przez trzy puszcze, PTTK, Warszawa, 127.

Rogalewski O, 1974: Zagospodarowanie turystyczne, WSiP, Warszawa, 159.

Saliszczew K. A., 1998: Kartografia ogólna, Wydawnictwo Naukowe PWN, Warszawa, 308.

Słoniewski E., 1998: Roztocze, PTTK, Warszawa, 208.

Stolarczyk S., 1984: Roztocze Środkowe, PTTK, Warszawa, 127.

Turystyka w 2007 r., 2008, Główny Urząd Statystyczny, Warszawa, 160.

Warszyńska J., Jackowski A., 1979: Podstawy geografii turyzmu. Wydawnictwo Naukowe PWN, Warszawa, 336.

Wilgat T. (ed.), 1994: Roztoczański Park Narodowy, RPN, Oficyna Wydawnicza „Ostoja”, Kraków, 243.

Wójcikowski W., Paczyński L., 1977: Roztocze, Sport i Turystyka, Warszawa, 263.

\section{Legal documents}

Ustawa z dnia 29 sierpnia 1997 r. o usługach turystycznych [Act of 29 August 1997 on tourist services], Dz. U. [Journal of Laws] 1997 no 133, item 884 with later amendments.

\section{Cartographic materials}

Mapa turystyczna Roztocze Środkowe, 1:125 000, PPWK, Warszawa, 1961.

Mapa turystyczna Roztocze Środkowe, 1:125 000, PPWK, Warszawa, 1968.

Mapa turystyczna Roztocze Środkowe, 1:125 000, PPWK, Warszawa, 1978.

Mapa turystyczna Roztocze Środkowe, 1:125 000, PPWK, Warszawa, 1984.

Mapa turystyczna Roztocze Środkowe, 1:100 000, PPWK, Warszawa, 1994.

Mapa turystyczno-przyrodnicza Roztoczański Park Narodowy, 1:50 000, Kartpol, Lublin, 2000.

Mapa turystyczno-przyrodnicza Roztoczański Park Narodowy, 1:50 000, Kartpol, Lublin, 2005.

Mapa turystyczna Roztocze Środkowe, 1: 50 000, Kartpol, Lublin, 2006. 


\section{STRESZCZENIE}

Zasadniczym celem przeprowadzonych badań było wykazanie zmian w przebiegu szlaków turystycznych i w rozmieszczeniu elementów punktowych infrastruktury turystycznej na obszarze Roztoczańskiego Parku Narodowego i w jego bliskim sąsiedztwie. Drugim, równie ważnym celem było sprawdzenie przydatności w badaniach infrastruktury turystycznej zarówno kartograficznej metody badań, jak i kartograficznych metod prezentacji.

Badaniami objęto rejon Roztoczańskiego Parku Narodowego. Wybrano następujące elementy infrastruktury turystycznej: elementy liniowe (piesze szlaki turystyczne i ścieżki poznawcze) oraz elementy punktowe (obiekty noclegowe, gastronomiczne oraz baza towarzysząca). Dla odtworzenia możliwie najbardziej dokładnie stanu infrastruktury w minionych 50 latach konieczne było poddanie analizie następujących materiałów źródłowych: map turystycznych wydawanych jako samoistne wydawnictwa oraz map zamieszczonych jako załączniki w przewodnikach i informatorach, a także archiwalnych zdjęć lotniczych. Skorzystano również z informacji zawartych w źródłach tekstowych, które stanowiły przewodniki turystyczne, informatory, foldery i monografie.

Zakres czasowy badań obejmował okres 50 lat, począwszy od lat 60. ubiegłego wieku do 2009 roku. Został on podzielony na pięć przedziałów czasowych, mniej więcej dziesiecioletnich. W celu przedstawienia stanu infrastruktury oraz jej przestrzennych i ilościowych zmian wykonano sześć map (mapy stanów i mapy typów zmian).

Przeprowadzone analizy przestrzenne oraz interpretacja treści map stanów i typów zmian infrastruktury turystycznej w poszczególnych okresach badawczych pozwoliła uchwycić zmiany zarówno ilościowe, jak i jakościowe. Stwierdzono, że zmiany w przebiegu szlaków nie były regularne. Istniały na przykład odcinki szlaków, które nie zmieniły swojego przebiegu przez 40 lat. Były również i takie, które powstały w ostatniej dekadzie. Obecnie badany obszar pokrywa gęsta sieć szlaków turystycznych i ścieżek poznawczych. Przeprowadzone pomiary długości szlaków turystycznych oraz ich odcinków z uwzględnieniem rodzaju pokrycia terenu i kategorii dróg pozwoliły określić charakter szlaków oraz wielkość zmian.

Badania wykazały dużą przydatność metod kartograficznych w badaniu infrastruktury turystycznej w aspekcie przestrzennym i ilościowym. 